DOI: 10.32089/WBH.PHW.2021.3(277).0004

ORCID: 0000-0002-5820-4845

Kamil KoŁodziej

Uniwersytet Śląski

\title{
Przysposobienie wojskowe podlległe 23 Górnośląskiej Dywizji Piechoty u schyłku lat trzydziestych XX w. Organizacja i zasady działania
}

\begin{abstract}
Military training (PW) is preparation of the pre-conscription population for military service, education of young people in the spirit of patriotism and civic responsibility. The research conducted so far has focused on national issues, highlighting the shortcomings of regional research in this matter. This article discuss the structure of the PW subordinate to 23 Infantry Division, its tasks and objectives, focusing largely on the area of the autonomous Silesian Voivodeship in the years 1937-1939.
\end{abstract}

\section{Zarys problematyki i tło wydarzeń}

Konieczność przygotowania rezerw i przysposobienia wojskowego (PW) ludności na wypadek wojny już od początków lat dwudziestych XX w. stanowiła dla władz państwowych poważne wyzwanie. Celem PW było nie tylko przygotowanie młodzieży przedpoborowej do regularnej służby wojskowej, ale i wychowanie jej w duchu patriotyzmu i odpowiedzialności obywatelskiej. Dotychczasowe badania poświęcone tej tematyce w dużej mierze skupiają się na problematyce ogólnokrajowej. Dotyczy to zarówno przyjmowanych przez władze państwowe strategii, jak i rozwoju instytucji wykonawczych. ${ }^{1}$ Zauważalny jest brak publikacji poświęconych regionalnym

Zob. Janusz Wojtycza, Przysposobienie Wojskowe w odrodzonej Polsce do roku 1926 (Kraków: Wyd. Naukowe Akademii Pedagogicznej, 2001); Janusz Odziemkowski, Armia 
działaniom PW, zwłaszcza dla obszarów wielonarodowych i przygranicznych w okresie poprzedzającym wybuch wojny. Większość badaczy skupia się na opisywaniu i charakterystyce działalności związków oraz organizacji PW i wychowania fizycznego (WF), a także tworzonych instytucji WF i PW na szczeblu centralnym państwa tuż po odzyskaniu niepodległości. Spośród prac poświęconych PW na obszarze kresów zachodnich państwa, z liczną mniejszością niemiecką, wyróżniają się prace Piotra Sai. ${ }^{2}$ Niedosyt opracowań widoczny jest również dla specjalistycznych formacji PW jak kolejarzy, leśników czy pocztowców. Na wyróżnienie zasługuje również praca Kazimierza Pindla umiejscawiająca Śląsk w całości systemu obronnego II Rzeczypospolitej. Odnosi się w niej również marginalnie do materii PW i jego wpływu na obronność regionu, zwłaszcza w drugiej połowie lat trzydziestych. Zdecydowanie więcej uwagi poświęcił sprawom innych organizacji paramilitarnych czy realizujących częściowo cele i zadania PW. ${ }^{3}$

Artykuł dotyczy lat 1937-1939. Symbolicznym punktem wyjścia jest czas rozbudowy struktur PW podległych 23 Dywizji Piechoty (DP) zakończony agresją Niemiec we wrześniu 1939 r. Działalność tych struktur przypadła na okres przygotowań do nadchodzącej wojny. Po wkroczeniu Niemców stanowiły fundament wielu organizacji konspiracyjnych tworzonych podczas okupacji. Przez wiele lat władze państwowe zmieniały koncepcje organizacji PW w Polsce. Stabilizacja i nadanie ostatecznego kształtu funkcjonowania nastąpiło $\mathrm{w}$ drugiej połowie lat trzydziestych. Zbieg z okresem rosnącego ryzyka wybuchu konfliktu zbrojnego spowodował możliwość ukazania pełni potencjału PW wykorzystanego także w przygotowaniach wojennych.

Schyłek 1937 r. to również czas rosnących napięć międzynarodowych. Doszło wówczas do przystąpienia Włoch do paktu antykominternowskiego i spotkania Adolfa Hitlera z brytyjskim ministrem Edwardem Halifaxem. Podjęta wtedy próba porozumienia nie zagwarantowała pokoju. Do najbardziej wyrazistych przykładów, mających miejsce już w 1938 r., należy Anschluss Austrii oraz konferencja monachijska i ostatecznie zajęcie Czechosłowacji. Wydarzenia te dotyczyły bezpośrednio bezpieczeństwa Polski

i społeczeństwo II Rzeczypospolitej (Warszawa: Bellona, 1996); Jan Kęsik, Naród pod broniq, Społeczeństwo w programie polskiej polityki wojskowej 1918-1939 (Wrocław: Wyd. Uniwersytetu Wrocławskiego, 1998).

2 Zob. Piotr Saja, „Przygotowanie wojskowe młodzieży szkolnej i obozy letnie przysposobienia wojskowego ogólnego męskiego na Pomorzu pod koniec lat dwudziestych i w latach trzydziestych XX wieku," Przegląd Historyczno-Wojskowy 20, nr 2 (268) (2019): 28-54, http://dx.doi.org/10.32089/WBH.phw.2019.2(268).0002; Saja, Komitety wychowania fizycznego i przysposobienia wojskowego w województwie pomorskim w okresie drugiej Rzeczypospolitej (Toruń: Piotr Saja, 2021).

3 Zob. Kazimierz Pindel, Śląsk w systemie obronnym II Rzeczypospolitej (Warszawa: Bellona, 1998). 
i regionu. Oddziały Wojska Polskiego stacjonujące na obszarze województwa śląskiego uczestniczyły w operacji wkroczenia na Zaolzie.

Polityka Hitlera nie zawsze oznaczała dla Polski konflikt. Po objęciu przez niego władzy Niemcy podpisały z Polską deklarację o niestosowaniu przemocy. ${ }^{4}$ Umowa ta doprowadziła do częściowej normalizacji i odprężenia stosunków między państwami. ${ }^{5}$ Było to szczególnie istotne dla funkcjonowania regionu, w którym działały organizacje niemieckie wrogo nastawione do Polaków od czasu powstań śląskich. Dochodziło do konfliktów z polskimi organizacjami kombatanckimi, paramilitarnymi czy młodzieżowymi. ${ }^{6}$ Ponowne zaostrzenie stosunków w województwie śląskim następowało stopniowo od przełomu 1938/1939 r., osiągając apogeum w sierpniu i wrześniu $1939 \mathrm{r}$.

Celem niniejszej publikacji jest przedstawienie struktur PW, jego funkcji i celów działania na obszarze stacjonowania jednostek wchodzących w skład 23 DP. Odnosząc się do podziału terytorialnego, należy wskazać, że poza obszarem samego województwa dowództwu dywizji w kwestiach PW podporządkowano także zachodnią część województwa krakowskiego i południową województwa kieleckiego. Kwestie zasięgu terytorialnego zostaną omówione szerzej w dalszej części artykułu. Praca skupia się w dużej mierze na strukturach męskiego PW skierowanego do młodzieży przedpoborowej. W przypadku odniesień do PW wyspecjalizowanych grup lub PW kobiet zostało to wyraźnie zaznaczone w tekście.

Najważniejszy organ państwowy realizujący cele PW powstał na mocy rozporządzenia Rady Ministrów z 28 stycznia 1927 r. Był to Państwowy Urząd Wychowania Fizycznego i Przysposobienia Wojskowego (PUWFiPW) podległy Ministerstwu Spraw Wojskowych (MSWojsk.) Organ ten miał zajmować się nadzorem, kontrolą, koordynowaniem działań związanych $\mathrm{z}$ wychowaniem fizycznym, PW oraz sportem. Pomimo zwierzchności wojskowej część kompetencji dotyczyła zadań Ministerstwa Wyznań Religijnych i Oświecenia Publicznego oraz Ministerstwa Spraw Wewnętrznych. Przeniesienie ciężaru przygotowań młodzieży do działalności propaństwowej i proobronnej z urzędów cywilnych na wojskowe było też pewnym wyrazem zwiększenia roli wojska w państwie po przewrocie majowym. Przez lata PUWFiPW wielokrotnie przechodził gruntowne

4 Deklaracja między Polską a Niemcami o niestosowaniu przemocy, podpisana w Berlinie dnia 26 stycznia 1934 r. (Dz. U. 1934, nr 16, poz. 124).

5 Andrzej Szefer, „Prowokacje hitlerowskie na Górnym Śląsku w przededniu agresji niemieckiej na Polskę w 1939 r.” w Śląsk wobec wojny polsko-niemieckiej 1939, red. Wojciech Wrzesiński (Wrocław-Warszawa: Wyd. Volumen, 1990), 129.

6 Tomasz Falęcki, Powstańcy śląscy 1921-1939 (Wrocław-Warszawa: Wyd. Volumen 1990), 192-196. 
reorganizacje, z których ostatnie miały miejsce w $1935^{7}$ i $1937^{8}$ r. W okresie poprzedzającym wybuch wojny instytucja ta była znacząco rozbudowana, współpracowała z licznymi organizacjami cywilnymi realizującymi zadania PW i WF. ${ }^{9}$

Śląskie struktury PW rozwijały się równolegle z ogólnokrajowymi. W czasie kształtowania się struktur wychowania fizycznego i PW tereny wschodniego i północno-wschodniego pogranicza kraju podporządkowano zwierzchnictwu Inspektoratów WF i PW Korpusu Ochrony Pogranicza. W latach 1927-1929 nastąpił rozwój ośrodków szkoleniowych WF w całym kraju. Ich głównym celem było wychowanie sportowe. Tężyzna fizyczna, zwinność czy wytrzymałość są do dziś oczywistymi atutami każdego rekruta. Wykorzystując ćwiczenia fizyczne, przy okazji realizowano również cele PW. Ośrodki powstawały przy Dowództwach Okręgów Korpusu (DOK) oraz w Wilnie, Łucku i Katowicach. ${ }^{10} \mathrm{~W}$ przypadku Katowic prawdopodobnie wynikało to z uwarunkowań geograficznych. Województwo śląskie było gęsto zaludnionym i rozwiniętym gospodarczo obszarem. DOK nr V zwierzchnie dla jednostek śląskich mieściło się w Krakowie i utworzenie dodatkowego ośrodka WF w Katowicach wynikało z dążenia do stworzenia centrum bliższego śląskiemu społeczeństwu. Dodatkowym atutem tego rozwiązania było powierzenie zadań ośrodkowi znającemu miejscową problematykę społeczną i teren. Władze ogólnopaństwowe, decydując się na Katowice, mogły oprzeć struktury WF i PW wyłącznie na 23 DP jako jedynej wielkiej jednostce wojskowej rozlokowanej praktycznie wyłącznie w granicach województwa śląskiego.

W swoich podstawowych założeniach PW miało przygotować obywateli do odbycia zasadniczej służby wojskowej. Z przyczyn oczywistych adresatami działań PW była głównie młodzież męska, która stanowiła fundament ówczesnych armii. Celem przygotowania przyszłych rekrutów było skrócenie właściwego szkolenia wojskowego w ramach poboru. Założeniem było również ułatwienie rekrutom zdobywania wyższych stopni w okresie służby. ${ }^{11}$ Wyspecjalizowane jednostki PW najczęściej działały przy instytucjach i jednostkach struktur aparatu państwowego, które mogły mieć

\footnotetext{
Przyjęcie kontroli przez państwo nad instytucjami i klubami sportowymi, tzw. „konstytucja sportu".

8 Wprowadzono zajęcia PW jako równoprawny przedmiot szkolny nauczany w godzinach lekcyjnych.

9 Zob. szerz. Wojtycza, „Państwowy Urząd Wychowania Fizycznego i Przysposobienia Wojskowego jako element koordynacji systemu bezpieczeństwa w II RP w latach 19271939," Bezpieczeństwo Teoria i Praktyka 5, nr 2 (2012): 85.

10 Ibid., 84.

11 Wojtycza, Przysposobienie Wojskowe, 5.
} 
bezpośrednie przełożenie na przebieg działań wojennych, spośród nich można wskazać np.: kolejowe przysposobienie wojskowe, pocztowe przysposobienie wojskowe, przysposobienie wojskowe leśników ${ }^{12}$ itp. W tym przypadku głównym celem nie było przygotowanie kolejarzy czy leśników do służby wojskowej, lecz jak najlepsze i sprawne wykorzystanie ich umiejętności zawodowych dla potrzeb obronnych państwa. W okresie pokoju, zwłaszcza w obszarach przygranicznych, specjalne jednostki PW odgrywały istotną rolę $\mathrm{w}$ rozpracowywaniu obcych bojówek i organizacji paramilitarnych oraz likwidacji tras nielegalnego przerzutu towarów i ludzi przez granicę państwową. W przypadku wybuchu wojny duże znaczenie odgrywała także znajomość terenu i specjalistycznej infrastruktury oraz umiejętności nabyte w czasie wykonywania pracy zawodowej.

\section{Charakterystyka regionalnej struktury przysposobienia wojskowego}

Ujednolicanie struktur PW w skali kraju rozpoczęło się w kwietniu $1928 \mathrm{r}$. Dokonało tego MSWojsk., które opierając się na obowiązującym wówczas wojskowym podziale administracyjnym kraju utworzyło okręgi WF i PW w istniejących 10 okręgach korpusów. Ich zasięg terytorialny i numeracja odpowiadały na zasadzie analogii tym okręgom. Dla 23 DP był to Okręg WF i PW nr 5 przy DOK nr V z siedzibą w Krakowie. Kierownictwo działalności związanej z PW spoczywało w gestii aktualnego dowódcy okręgu korpusu. Obowiązek ten dotyczył niezwykle rozległego pola i w gruncie rzeczy niepierwszorzędnego celu piastowania tak odpowiedzialnego stanowiska. Odciążeniem dowódcy na tym polu była działalność Okręgowego Urzędu WF i PW (OUWFiPW) danego DOK. Na jego czele stał kierownik podporządkowany służbowo bezpośrednio dowódcy okręgu korpusu.

Okręg koordynował i nadzorował pracę podległych sobie urzędów PW. $\mathrm{Z}$ reguły przy wielkich jednostkach tworzono rejony PW. Dla województwa śląskiego i sąsiednich terenów powstał rejon 23 DP. Niżej w drabinie strukturalnej PW znajdowały się komendy obwodowe oraz komendy powiatowe, koła miejscowe i hufce szkolne. Zdarzały się sytuacje, w których z różnych względów nie udało się utworzyć powiatowych struktur PW, wówczas zazwyczaj na takich obszarach działały miejscowe koła PW w bardziej aktywnych miejscowościach. Istotnym elementem były również organizowane hufce szkolne. Ze względu na braki źródłowe niezwykle trudno jednoznacznie wyodrębnić poszczególne szczeble struktur PW. Próbę odtworzenia umożliwia przede wszystkim zachowana dokumentacja związana z zamówieniami na amunicję dla poszczególnych komend PW (zob. tabela 1).

12 Określane także „przysposobieniem wojskowym gajowych”. 


\section{Tabela 1. Struktury PW podległe $23 \mathrm{DP}$}

\begin{tabular}{|l|}
\hline Komenda Rejonu PW 23 DP \\
\hline Komenda Rejonu Konnego PW 23 DP \\
\hline Komenda Rejonu PW 21 DP Górskiej \\
\hline Komenda Rejonu PW Konnego 3 Pułk Ułanów \\
\hline Komenda Obwodu PW nr 73 Katowice \\
\hline Komenda Obwodu PW nr 73 Sosnowiec \\
\hline Komenda Obwodu PW nr 93 Bielsko \\
\hline Komenda Obwodu PW nr 193 Oświęcim \\
\hline Komenda Obwodu PW nr 75 Chorzów \\
\hline Komenda Obwodu PW nr 175 Rybnik (obejmowała także Kom. Obw. PW Mikołów) \\
\hline Komenda Obwodu PW nr 94 Cieszyn \\
\hline Komenda Obwodu PW nr 11 Tarnowskie Góry \\
\hline Komenda Obwodu PW nr 111 Zawiercie \\
\hline
\end{tabular}

Źródło: Opracowanie własne autora na podstawie zgłoszeń zapotrzebowania na amunicję do szkolenia PW na rok szkolny 1938/1939, Centralne Archiwum Wojskowe Wojskowego Biura Historycznego (dalej: CAW-WBH), 23 Dywizja Piechoty (dalej: 23 DP), sygn. I.313.23.16, Zapotrzebowanie amunicji 23 Dywizja Piechoty Rejon WF i PW L.dz. 446/Tj., Katowice, 4 XI 1938 r., b.p.

Przedstawione informacje wskazują przede wszystkim dwie kwestie. $\mathrm{Z}$ jednej strony można dostrzec, że niektóre z jednostek PW cechują się odmienną strukturą. Konne PW zostało przypisane do osobnego rejonu przyporządkowanego nie tylko do $23 \mathrm{DP}$, ale i 3 Pułkowi Ułanów Śląskich. Świadczy to o wyjątkowości tego rodzaju PW, którego przynależność wynikała z próby objęcia większego obszaru terytorialnego możliwie licznymi jednostkami kawalerii. Oczywiste jest, że 23 DP posiadała na stanie konie, ale to jednostki kawaleryjskie mogły skuteczniej szkolić w tym zakresie. Powodowało to rozciągnięcie rejonów konnych PW na większe obszary DOK nr V. Tabela jednoznacznie wskazuje, że rejon 23 DP obejmuje terytoria znajdujące się poza granicami województwa śląskiego, o czym szerzej w dalszej części pracy.

Poszczególne szczeble PW miały przede wszystkim za zadanie nadzór nad podległymi komendami i organizację współpracy z innymi organizacjami i związkami WF i PW na podległym terenie. Do najważniejszych z nich zaliczano Związek Strzelecki i Związek Powstańców Śląskich. Dla mieszkańców szczególnie bliskimi były powiatowe komendy jednoczące dorosłych i hufce szkolne pracujące z młodzieżą. Przez cały okres istnienia PW dużym problemem były braki wykształconej i doświadczonej kadry. Szczególnie dotkliwe było to w latach poprzedzających wybuch wojny ze względu na rozrost liczby kół miejscowych i hufców szkolnych oraz przesunięcia kadrowe wynikłe z tworzenia jednostek Obrony Narodowej (ON). Starano się obsadzać stanowiska dowódcze wszystkich szczebli PW oficerami 
zawodowymi lub w ostateczności oficerami rezerwy. W miarę możliwości mieli być oni $\mathrm{w}$ jakiś sposób związani $\mathrm{z}$ terenem, którym kierowali, np. odbywali tam służbę wojskową bądź wywodzili się z niego. Dotyczyło to przede wszystkim struktur miejscowych i powiatowych, w ten sposób kierownictwo PW mogło lepiej rozumieć sytuację i potrzeby na terenie swoich działań. Ważnym elementem niższych szczebli była organizacja szkoleń PW i przygotowań letnich obozów.

Na początku 1937 r. zakończono szkolenia pierwszych oddziałów ON. Okręg Korpusu nr V mógł oddelegować w 1937 r. do oddziałów ON przez cały rok 4 oficerów i 10 podoficerów. Sytuacja wyglądała nieco lepiej w miesiącach zimowych, kiedy realne było oddelegowanie 36 oficerów i 72 podoficerów. Rozwiązaniem problemu miało być włączenie do tworzenia jednostek struktur PW. Po wielu konferencjach wewnętrznych MSWojsk. uznano, że ON nie będzie kontynuacją czy wyższym etapem PW. Nie przewidywano koszarowania tych jednostek, co przyniosło wymóg tworzenia ich z miejscowej ludności. Zalążkami oddziałów były często miejscowe organizacje paramilitarne. Z PW organizowano i obsadzano stanowiska dowódcze. Najzdolniejsi członkowie organizacji paramilitarnych i PW mieli również zasilić szeregi oddziałów. Śląsk uznano za newralgiczny element granicy państwowej i przewidywano w przypadku zagrożenia sformowanie 8 batalionów ON, które szybko mogły przerodzić się w dywizję rezerwową ${ }^{13}$ Sprawność struktur PW i przeszkolenie mieszkańców regionu miało więc bezpośrednie przełożenie na formowanie oddziałów ON.

Zarządzeniem MSWojsk. 1 lutego $1937 \mathrm{r}$ utworzono rejon PW dla 23 DP. Pod względem organizacji, wyszkolenia oraz użycia oddziałów PW w wypadku wojny lub szeroko rozumianego niebezpieczeństwa podporządkowano je bezpośrednio dowódcy dywizji. Stanowisko to obejmował wówczas płk dypl. Jan Jagmin-Sadowski. ${ }^{14} \mathrm{Za}$ wszystkie podjęte działania dotyczące PW odpowiadał bezpośrednio przed dowódcą OK nr V. Pomimo dyslokacji dywizji głównie na obszarze województwa śląskiego w sprawach PW jej dowódca sprawował komendę i nadzór nad obwodami położonymi w łącznie trzech województwach. Z województwa śląskiego były to Chorzów, Katowice miasto, Katowice powiat, Pszczyna, Rybnik, Świętochłowice i Tarnowskie Góry. Z województwa krakowskiego włączono Chrzanów, natomiast $\mathrm{z}$ kieleckiego Będzin, Olkusz, Sosnowiec miasto oraz Zawiercie. Przyjęty wówczas podział terytorialny utrzymał się aż do upadku państwa w 1939 r. Wraz z utworzeniem rejonu PW przy 23 DP kompetencje kierownika OUWFiPW przy DOK nr V ograniczone zostały do spraw

13 Pindel, Obrona terytorialna w II Rzeczypospolitej (Warszawa: Bellona, 1995), 111-114.

14 Przed wybuchem wojny otrzymał awans na generała brygady. 
administracyjno-gospodarczych i materiałowych. Rozkaz wydał minister spraw wojskowych gen. bryg. Tadeusz Kasprzycki. ${ }^{15}$

Przesunięcie części kompetencji na rzecz dowódcy 23 DP miało na celu sprawniejsze funkcjonowanie podległych struktur powiatowych i gminnych, pozwalając na szybsze i sprawniejsze zarządzenie nimi. Pozostawienie kwestii administracyjnych oraz gospodarczych w rękach kierownika OUWFiPW przy DOK nr V w Krakowie wynikało z konieczności zastosowania rozwiązań ogólnokrajowych, a także rozdysponowania środków pozostających do dyspozycji DOK. W gestię dowódcy dywizji przekazano m.in. nadzór nad miejscowymi organizacjami PW, opiniowanie szkoleń i projektów, koordynację miejscowych działań czy nadzór nad obozami szkoleniowymi PW.

Struktura PW na Śląsku została doprecyzowana w rozkazie wykonawczym wydanym 9 kwietnia 1937 r. w Warszawie przez I wiceministra spraw wojskowych gen. bryg. Janusza Głuchowskiego. Rozkaz ten uprawniał dowódcę $23 \mathrm{DP}$ do podporządkowania obwodów i powiatów PW, pod względem zadań specjalnych, poszczególnym dowódcom jednostek organizacyjnych wojska. Mógł to czynić według uznania, niezależnie od ustalonego podziału terytorialnego. Do jego kompetencji należało również przedstawianie wniosków dotyczących obsady personalnej oficerów kierownictwa rejonu PW 23 DP. Składano je do Biura Personalnego MSWojsk. poprzez dowódcę OK nr V i dyrektora PUWFiPW. Ponadto dyrektor został zobowiązany dostosować podział organizacyjny związków: Harcerstwa Polskiego, Strzeleckiego i Rezerwistów do organizacji PW. Zastępca kierownika rejonu PW 23 DP pełnił jednocześnie obowiązki komendanta Podokręgu Śląskiego Związku Strzeleckiego. ${ }^{16}$ Organizacje te należały do najważniejszych realizujących cele $\mathrm{PW} \mathrm{w}$ omawianym regionie, gdyż były silnie związane z miejscowymi strukturami PW w zakresie wspólnej działalności. Należy również podkreślić istotną rolę Związku Powstańców Śląskich, która była szczególnie ważna na polu podtrzymywania sprawności wojskowej ludności cywilnej, w tym rezerwistów, zwłaszcza w zakresie cyklicznych ćwiczeń.

Problematyka struktur podległych 23 DP to nie tylko kwestia zasięgu terytorialnego. Dzięki zachowanej dokumentacji można odtworzyć również liczbę etatów oficerów i podoficerów zawodowych w komendach obwodowych i powiatowych PW oraz ośrodkach WF (zob. tabela 2). Informacje zawarte $\mathrm{w}$ tabeli przede wszystkim wskazują nasycenie struktur kadrą oficerską i podoficerską.

15 CAW-WBH, 23 DP, sygn. I.313.23.13, Zarządzenie Ministra Spraw Wojskowych Departamentu Dowodzenia Ogólnego, L. 6557/Org.Tjn.36, Warszawa, 22 I 1937 r., 1-2. Ze względu na brak paginacji teczki podana paginacja jest paginacją dokumentu, dotyczy to wszystkich cytowań materiałów z zasobu CAW-WBH.

16 Ibid., Rozkaz wykonawczy Ministerstwa Spraw Wojskowych Departamentu Dowodzenia Ogólnego, L. 1607/Org.tj., Warszawa z dnia 9 IV 1937 r. , b.p. 
Tabela 2. Podział terytorialny i liczba etatów oficerów i podoficerów w komendach PW $w$ rejonie 23 DP

\begin{tabular}{|c|c|c|c|c|c|c|c|c|}
\hline \multirow[t]{3}{*}{ DP } & \multirow{3}{*}{$\begin{array}{l}\text { Komendy } \\
\text { obwodów } \\
\text { PW }\end{array}$} & \multirow{3}{*}{$\begin{array}{c}\text { Komendy powiatowe } \\
\text { względnie miejskie ośrodki } \\
\text { WF }\end{array}$} & \multicolumn{6}{|c|}{ Ze składu osobowego wojska } \\
\hline & & & \multicolumn{3}{|c|}{ Oficerowie } & \multicolumn{3}{|c|}{ Podofic. zaw. } \\
\hline & & & $\stackrel{\frac{a}{\pi}}{\sum^{3}}$ & 䒿 & 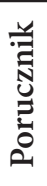 & 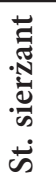 & • & 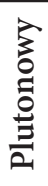 \\
\hline \multirow{15}{*}{ 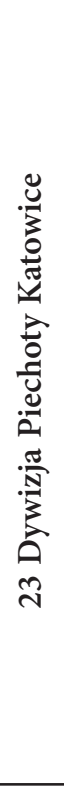 } & \multirow{5}{*}{$\begin{array}{l}11 \text { pp } \\
\text { Tarnowskie } \\
\text { Góry } \\
\text { Nr } 11\end{array}$} & & 1 & & & 1 & & \\
\hline & & Tarnowskie Góry & & 1 & & & 1 & 1 \\
\hline & & Zawiercie & & 1 & & & 1 & 1 \\
\hline & & Będzin (bez gminy Bobrowniki) & & 1 & & & 1 & 1 \\
\hline & & Olkusz & & 1 & & & 1 & 1 \\
\hline & \multirow{6}{*}{$\begin{array}{l}73 \mathrm{pp} \\
\text { Katowice } \\
\mathrm{Nr} 11\end{array}$} & & 1 & & & 1 & & \\
\hline & & Katowice miasto & & 1 & & & 1 & 1 \\
\hline & & \begin{tabular}{|l}
$\begin{array}{l}\text { Katowice powiat I. } \\
\text { (część wschodnia) }\end{array}$ \\
\end{tabular} & & 1 & & & 1 & 1 \\
\hline & & Sosnowiec miasto & & 1 & & & 1 & 1 \\
\hline & & Chrzanów & & 1 & & & 1 & 1 \\
\hline & & Ośrodek WF & & 1 & & & 1 & \\
\hline & \multirow{4}{*}{$\begin{array}{l}75 \text { pp } \\
\text { Chorzów } \\
\text { Nr } 75\end{array}$} & & 1 & & & 1 & & \\
\hline & & Chorzów miasto & & 1 & & & 1 & 1 \\
\hline & & $\begin{array}{l}\text { Świętochłowice I. } \\
\text { (z gminą Bobrowniki } \\
\text { w pow. będzińskim) } \\
\end{array}$ & & 1 & 1 & & 1 & 1 \\
\hline & & \begin{tabular}{|l}
$\begin{array}{l}\text { Katowice powiat } \\
\text { (część zachodnia) }\end{array}$ \\
\end{tabular} & & 1 & & & 1 & 1 \\
\hline
\end{tabular}

Źródło: CAW-WBH, 23 DP, sygn. I.313.23.13, Załącznik nr 2. do rozkazu M.S. Wojsk. Dep. Dow. Og L.1607/Org.tj.37r z dnia 9 IV 1937 r., Warszawa Podział Terytorialny i składy osobowe P.W. w Rejonie 23 Dywizji Piechoty, Warszawa, 9 IV 1937 r., b.p.

Należy podkreślić, że oryginalny maszynopis znajdujący się w dokumentacji 23 DP posiada wiele odręcznych uzupełnień. Prawdopodobnie było to efektem pewnej płynności struktur terytorialnych wynikających z dynamicznie rozwijających się komend powiatowych i kół PW u schyłku lat trzydziestych w rejonie $23 \mathrm{DP}^{17}$

Istotną zmianą było połączenie obwodów białego i bielskiego $\mathrm{w}$ jeden, wspólny obwód. Decyzja o tym zapadła w MSWojsk. (w ramach PUWFiPW)

17 Ibid., Załącznik nr 2. Do rozkazu M.S. Wojsk. Dep. Dow. Og L.1607/Org.tj.37r Podział Terytorialny i składy osobowe P.W. w Rejonie 23 Dywizji Piechoty, Warszawa, 9 IV 1937 r., b.p. 
rozkazem ogólnym z 17 sierpnia 1938 r. Postanowiono wówczas o wyłączeniu miasta Biała z obwodu w Oświęcimiu i włączeniu go w ramy obwodu bielskiego. Temu zabiegowi przyświecały trzy zasadnicze idee. Po pierwsze, zdawano sobie sprawę, że w ten sposób niejako wzmocniona zostanie polskość w Bielsku, miejscowości o silnej mniejszości niemieckiej. Zwiększenie obecności i widoczności młodzieży polskiej było pożądanym przez władze efektem tej decyzji. Po drugie, zmiana ta doprowadziła do połączenia Związku Strzeleckiego, Związku Rezerwistów i organizacji PW o podobnym charakterze, które dzięki temu zyskały na sile i znaczeniu. Trzecim czynnikiem, niejako bardziej technicznym, było oddalenie Białej od Oświęcimia, które utrudniało staranną opiekę nad tymi strukturami w rejonie. Bielsko położone było znacznie bliżej, więc zakładano poprawę funkcjonowania struktur PW..$^{18}$

W zabiegu tym widoczna jest również świadomość władz wojskowych z korzyści odejścia od administracyjnego podziału kraju oraz wad stacjonowania niektórych oddziałów na terenie zbyt rozległym dla efektywnego rozwoju PW. Skupienie zadań PW wokół bliższego ośrodka innej dywizji było korzystnym manewrem dla rozwoju tamtejszego ruchu PW. Bielsko było miastem garnizonowym 3 Pułku Strzelców Podhalańskich (pspodh.) wchodzących w skład 21 DP Górskiej (DPG). Prawdopodobnie podobnymi pobudkami kierowano się w kwestii włączenia polskiej części Zaolzia. W Cieszynie stacjonował 4 pspodh. Może o tym świadczyć liczne rozmieszczenie obozów PW dla młodzieży szkolnej na Śląsku cieszyńskim. Sprawozdania z tych turnusów adresowano do kierownictwa PW przy 23 DP. Ponadto zarówno $23 \mathrm{DP}$, jak i $21 \mathrm{DPG}$ były podporządkowane jednemu DOK w Krakowie. Przesunięcia zwierzchności nad komendami oraz związkami i stowarzyszeniami PW nie zmieniały więc zwierzchnictwa na szczeblu okręgu. Po wkroczeniu Wojska Polskiego na Zaolzie w październiku 1938 r. ziemie przyłączone do Polski zostały również przydzielone do rejonu 23 DP.

Dla śląskich struktur PW ważną postacią był płk Józef Giza. Znany jest przede wszystkim jako dowódca Górnośląskiej Brygady ON z Katowic, na bazie której w przededniu wojny zmobilizowano 55 Rezerwową DP. Obowiązki kierownika rejonu PW i WF 23 DP objął w czerwcu 1938 r., zastępując na tym stanowisku płk. Antoniego Własaka. Wyznaczenie właśnie płk. Gizy na to stanowisko przypuszczalnie było efektem jego pracy społecznej i oświatowej, jaką podejmował wcześniej, będąc dowódcą 3 pspodh. stacjonującego w Bielsku. Dał się poznać wówczas jako dobry organizator,

\footnotetext{
18 Ibid., sygn. I.313.23.16, Pismo Ministerstwa Spraw Wojkkowych[,] Państwowy Urząd Wychowania Fizycznego i Przysposobienia Wojskowego dotyczące rozkazu nr 1354/Og. z dnia 17 VIII 1938, Warszawa, b.p.
} 
chętnie nawiązujący współpracę z lokalnym społeczeństwem. ${ }^{19}$ Wydawał się więc idealnym kandydatem na tak znaczącym i zarazem niespokojnym, wielonarodowym obszarze. Pełniąc stanowisko kierownika rejonu PW i WF przy 23 DP, zajmował się koordynowaniem działań organizacji PW, nadzorem szkoleń i młodzieżowych obozów PW, jak i pracą z wyspecjalizowanymi grupami. Stanowisko to należy rozpatrywać jako urząd wykonawczy wobec decyzji dowódcy 23 DP i DOK nr V.

\section{Współpraca $\mathrm{z}$ innymi organizacjami realizującymi cele $\mathrm{PW}$ i stosunek do lokalnego społeczeństwa}

Im bliżej 1939 r., tym MSWojsk. wydawało coraz więcej upoważnień dla stowarzyszeń i organizacji społecznych do prowadzenia szkoleń z zakresu PW. Na obszarze całego kraju były to: Związek Strzelecki, Związek Towarzystw Gimnastycznych „Sokół”, Związek Powstańców i Wojaków, Związek Powstańców Śląskich, Związek Osadników Wojskowych, Związek Ochotniczych Straży Pożarnych, Zjednoczenie Młodzieży Polskiej. Wyłącznie te organizacje mogły współpracować z władzami wojskowymi w związku ze szkoleniem PW. ${ }^{20}$ Wiele celów z zakresu PW realizowało harcerstwo. W przededniu wybuchu wojny kręgi skautów i starszoharcerskie zaangażowały się właśnie poprzez PW we wzmocnienie obronności regionu. ${ }^{21}$ Dla struktur omawianego regionu szczególnie istotną rolę odgrywał Związek Powstańców Śląskich skupiający osoby, które stanowiły przykład dla młodzieży, walcząc kilkanaście lat wcześniej o polskość tych ziem.

Jednym z podstawowych celów PW było dotarcie do jak najszerszych kręgów społeczeństwa. Organy PW starały się nawiązać, przynajmniej symboliczną, współpracę z innymi organizacjami o podobnym charakterze. Zwracano się do: Związku Strzeleckiego, ZHP, Sokoła, Związku Młodej Wsi z prośbą o wydawanie odezw, mających na celu propagowanie działań na rzecz obronności. Poprzez te organizacje zamierzano dotrzeć do obywateli niezwiązanych z PW. Odezwy miały być środkiem zachęcenia

19 Ibid., sygn. I.313.23.20, Sprawozdanie z realizacji programu P.W. Kierownika 23 Dywizji Piechoty L.dz. 477/tj./P.W. Katowice z dnia 15 V 1939 r., Katowice, b.p.; zob. szerz. o Józefie Gizie: Tomasz Podgórski, Generał Józef Giza 1887-1965 Virtute et armis (Nowy Sącz-Kraków: Wyd. Flexergis, 2015); Maria Giza-Podgórska, Z Sącza rodem wspomnienia córki generała Józefa Gizy (Nowy Sącz: Sądecka Ofic. Wyd., 1993).

20 Józef Hildebrandt, „Zinstytucjonalizowane przysposobienie wojskowe w Polsce w latach 1918-1939," Zeszyty Naukowe Wyższej Szkoły Pedagogicznej w Bydgoszczy Studia z Nauk Społecznych 11, (1994): 85.

${ }^{21}$ Wojciech Niederliński, „W wolnej Polsce. Harcerstwo męskie w latach 1922-1939,” w Z dziejów harcerstwa śląskiego Rozwój i działalność harcerstwa na Górnym Śląsku w latach 1920-1945, red. Wojciech Janota (Katowice: Wyd. „Śląsk”, 1985), 124. 
niezdecydowanej części ludności do zaangażowania się w działania prowojskowe i proobronne państwa. Starano się nie tyle wykorzystywać te organizacje do werbunku wojskowego, lecz przekonać jak największą część społeczeństwa do wstąpienia w szeregi pozwalające uzyskać przygotowanie wojskowe. ${ }^{22}$

Podstawową motywacją i zachętą do angażowania się w ruch PW było przedstawianie korzyści płynących z posiadania stopni PW w okresie odbywania zasadniczej służby wojskowej. Żołnierze należący wcześniej do hufców szkolnych, stowarzyszeń i organizacji PW, posiadający przy tym stopnie PW, otrzymywali często możliwość wyboru rodzaju broni, w ramach przedstawionych im opcji. Łatwiej otrzymywali przepustki na święta czy też mieli w ogóle możliwość otrzymywania przepustek pozwalających opuszczać koszary w okresie pozostawania rekrutem. Starano się również ułatwić im dostęp do szkół oficerskich. Oczywiście samo przeszkolenie w organizacjach PW nie było jedynym warunkiem. Od zainteresowanych dostaniem się na kurs lub do szkoły umożliwiającej otrzymanie wyższego stopnia wymagano również prezentacji odpowiedniej postawy żołnierskiej przejawiającej się głównie w bezwzględnej dyscyplinie i sumienności w wykonywaniu obowiązków służbowych. Dodatkową zachętą dla ludzi o niezbyt wygórowanych ambicjach wojskowych była możliwość skrócenia okresu służby czynnej o trzy miesiące. W praktyce przejawiała się ona późniejszym powołaniem do wojska. ${ }^{23}$

\section{Hufce szkolne PW}

Nauczanie PW w placówkach oświatowych wprowadzone zostało, na określonych warunkach, już w 1923 r. W 1931 r. wszedł w życie program zakładający prowadzenie zajęć w klasach VI i VII szkół średnich ogólnokształcących, III i IV kursie seminariów nauczycielskich, na II i III roku w zawodowych szkołach średnich, na I i II roku w szkołach wyższych oraz dla uczniów, którzy ukończyli 16 rok życia w innych szkołach zawodowych. ${ }^{24} \mathrm{~W} 1937$ r. PW stało się równoprawnym przedmiotem szkolnym, którego nauczano w czasie zajęć lekcyjnych, a ocena końcowa trafiała na świadectwa szkolne. ${ }^{25}$ Wprowadzenie PW do programu nauczania sprawi-

\footnotetext{
22 CAW-WBH, 23 DP, sygn. I.313.23.16, Poufne pismo Powiatowej Komendy P.W. Żywiec do Kierownika Rejonu W.F. i P.W. w Katowicach, Żywiec, 6 IX 1938 r., 3.

23 Zob. szerz. Mieczysław Fularski, Przysposobienie wojskowe w Polsce (Warszawa: Wyd. Głównej Księgarni Wojskowej, 1929).

24 Wojtycza, „Państwowy Urząd Wychowania,” 85.

25 Krzysztof Zaczyński-Zaczek, „Programy przysposobienia wojskowego w II Rzeczypospolitej," Przysposobienie Obronne - Obrona Cywilna w Szkole, nr 4 (1992): 205.
} 
ło, że przekazywane treści trafiały do znacznie szerszego grona odbiorców. Wymóg wpisywania ocen $\mathrm{z}$ tego przedmiotu na świadectwa musiał przełożyć się na zwiększenie starań młodzieży w pogłębianiu wiedzy z tej materii. Władze wojskowe zyskały możliwość wstępnej oceny rekruta, choćby na podstawie ocen szkolnych. Taki stan rzeczy dotyczył również zainteresowanych dalszym rozwijaniem swoich umiejętności i wiedzy w ramach $\mathrm{PW}$, organizacje i instytucje realizujące PW również brały pod uwagę ocenę z przedmiotu szkolnego.

Aktem prawnym wprowadzającym PW do szkół powszechnych dla uczniów od 15 lat wzwyż było zarządzenie ministra wyznań religijnych i oświecenia publicznego oraz ministra spraw wojskowych z 10 września 1937 r. Młodzież objęta PW tworzyła hufce noszące nazwę i numer szkoły. Ich organizacja, opieka i kontrola nad nimi spoczywała na dyrektorze oraz radzie pedagogicznej danej szkoły. Komendantem hufca szkolnego mógł zostać nauczyciel posiadający stopień oficera lub podchorążego rezerwy. W przypadku braku kandydatów spośród nauczycieli szkoły, spełniających wspomniane kryteria, zarządzenie przewidywało możliwość powierzenia tej funkcji oficerowi lub podchorążemu rezerwy będącemu absolwentem danej placówki oświatowej. W ostateczności komendant obwodu PW wyznaczał na to stanowisko oficera służby stałej. Na komendancie obwodu spoczywał również obowiązek nadzoru fachowego nad poszczególnymi hufcami szkolnymi. ${ }^{26}$

Wprowadzenie PW do szkół z pewnością przełożyło się również na szkolne obozy PW, będące elementem praktycznego szkolenia i zdobywania stopni PW, które zgodnie z przyjętym systemem były dwa. Uczniowie angażujący się w szkolenie, którzy wykazali się wiedzą i umiejętnościami praktycznymi, mieli szansę udziału w wakacyjnym obozie PW. Była to dla nich możliwość sprawdzenia swojej wiedzy, rozwoju umiejętności i uzyskania wyższego stopnia PW oraz bliższego obcowania $\mathrm{z}$ wojskowym stylem życia. Młodzież postrzegała obozy również jako atrakcyjną formę spędzania wakacji.

Bardzo trudno określić jednoznacznie liczbę szkolnych hufców PW dla rejonu PW 23 DP nawet w 1939 r. W tym czasie bez wątpienia nastąpił szczyt rozwoju śląskich struktur PW przerwany wybuchem wojny z Niemcami. W zachowanych źródłach trudno doszukać się pełnych spisów czy kompleksowych sprawozdań. Podjęcie próby wskazania przynajmniej najważniejszych hufców szkolnych możliwe jest na podstawie zachowanych sprawozdań z działalności PW skierowanych do Wydziału Oświecenia Publicznego Urzędu Wojewódzkiego Śląskiego w Katowicach w latach 19371939 (zob. tabela 3).

26 Zarządzenie Ministra W. R. i O. P. oraz Ministra Spraw Wojskowych z dnia 10 września 1937 r. w sprawie organizacji przysposobienia młodzieży szkolnej do obrony kraju (Dz. Urz. Ministra Wyznań Religijnych i Oświecenia Publicznego, nr 12, poz. 369, 439, §3, 5). 
Tabela 3. Hufce szkolne PW podległe rejonowi PW 23 DP.

\begin{tabular}{|c|c|c|}
\hline Lp. & Miejscowość & Szkoła \\
\hline 1. & Katowice & $\begin{array}{l}\text { Państwowe Gimnazjum } \\
\text { Prywatne Gimnazjum Świętego Jacka } \\
\text { Miejskie Gimnazjum } \\
\text { Miejskie Gimnazjum Kupieckie }\end{array}$ \\
\hline 2. & Siemianowice & Państwowe Gimnazjum \\
\hline 3. & Chorzów & $\begin{array}{l}\text { Miejski Instytut Kształcenia Handlowego } \\
\text { Państwowe Gimnazjum im. Odrowążów } \\
\text { Państwowe Gimnazjum im. Stanisława Kostki }\end{array}$ \\
\hline 4. & Nowa Wieś & Państwowe Gimnazjum \\
\hline 5. & Mysłowice & Państwowe Gimnazjum \\
\hline 6. & Mikołów & $\begin{array}{l}\text { Państwowe Gimnazjum } \\
\text { Prywatne Gimnazjum ks. Salw. }\end{array}$ \\
\hline 7. & Tarnowskie Góry & $\begin{array}{l}\text { Państwowe Gimnazjum } \\
\text { Liceum Pedagogiczne }\end{array}$ \\
\hline 8. & Lubliniec & Państwowe Gimnazjum \\
\hline 9. & Piekary Śląskie & Państwowe Gimnazjum \\
\hline 10. & Ruda Śląska & Komunalne Gimnazjum \\
\hline 11. & Rybnik & $\begin{array}{l}\text { Państwowe Gimnazjum } \\
\text { Komunalne Gimnazjum Kupieckie }\end{array}$ \\
\hline 12. & Żory & Państwowe Gimnazjum \\
\hline 13. & Cieszyn & $\begin{array}{l}\text { Państwowe Liceum Pedagogiczne } \\
\text { I Państwowe Gimnazjum } \\
\text { II Państwowe Gimnazjum } \\
\text { III Państwowe Gimnazjum } \\
\text { Państwowe Gimnazjum Kupieckie } \\
\text { Prywatna Szkoła Rzemieślnicza }\end{array}$ \\
\hline 14. & Pszczyna & $\begin{array}{l}\text { Państwowe Gimnazjum } \\
\text { Państwowe Liceum Pedagogiczne }\end{array}$ \\
\hline 15. & Bielsko & $\begin{array}{l}\text { Państwowe Gimnazjum } \\
\text { Państwowa Szkoła Przemysłowa }\end{array}$ \\
\hline 16. & Bogumin & Państwowe Gimnazjum \\
\hline 17. & Orłowa & $\begin{array}{l}\text { I Państwowe Gimnazjum } \\
\text { II Państwowe Gimnazjum } \\
\text { Państwowa Szkoła Kupiecka }\end{array}$ \\
\hline 18. & Karwina & Państwowa Szkoła Przemysłowa \\
\hline 19. & Nowy Bytom & Szkoła Rzemieślnicza \\
\hline
\end{tabular}

Źródło: Opracowanie własne autora na podstawie dokumentacji Wydziału Oświecenia Publicznego Urzędu Wojewódzkiego Śląskiego: Archiwum Państwowe w Katowicach (dalej: AP w Katowicach), Urząd Wojewódzki Śląski w Katowicach, 12/27/0/13.1/547, Przysposobienie wojskowe w szkołach - organizacja hufców szkolnych 1937-1939. 
Przedstawione dane wskazują, że hufce szkolne były organizowane w miejscowościach powiatowych. Wynika to z istnienia tam szkół, do których uczęszczała już starsza młodzież objęta obowiązkiem nauki PW. Oczywiście nie jest to tożsame ze stwierdzeniem, że tabela wskazuje wszystkie szkolne hufce PW. Znajdują się tam jedynie te, które znalazły się w zachowanych sprawozdaniach, bez informacji o ich likwidacji czy zawieszeniu działalności spowodowanej np. brakiem kadry instruktorskiej. Niespójność i szczątkowość zachowanych danych nie pozwala na oszacowanie liczebności omawianych hufców.

Natomiast wynika z tabeli jednoznacznie, że we wszystkich większych miastach województwa śląskiego działał przynajmniej jeden hufiec szkolny. Po przyłączeniu Zaolzia do Polski szkoły tam się znajdujące również zostały włączone do struktur PW rejonu 23 DP. Warto podkreślić, że hufce były organizowane także w prywatnych szkołach.

\section{Zadania związków i stowarzyszeń PW w okresie poprzedzającym wybuch wojny}

W związku z rosnącym zagrożeniem ze strony Niemiec improwizowane grupy członków organizacji PW i WF brały udział w akcjach zabezpieczenia województwa przed infiltracją członków niemieckich grup dywersyjnych. Oddziały PW i WF zmobilizowano do prac na podstawie wytycznych DOK nr V z 29 kwietnia 1939 r. Działania na terenie województwa śląskiego nadzorował kierownik rejonu WF i PW płk Giza. Prace grup PW można podzielić na zadania zewnętrzne i wewnętrzne. ${ }^{27}$

Zadania zewnętrzne skupiały się przede wszystkim na wzmocnieniu sił Straży Granicznej działającej na terenie województwa śląskiego. Do takich działań zmusiło dowództwo dywizji ryzyko szerszych akcji mniejszości niemieckiej oraz państwa niemieckiego. Wzmocniono więc wszystkie placówki Straży Granicznej tzw. pierwszej, drugiej, trzeciej linii, a także komisariaty straży. W działaniach tych brały także udział pododdziały Związku Strzeleckiego i Powstańców Śląskich. Oddziały PW na zachód od linii rzek Brynicy, Przemszy i Wisły skupiano przy kompaniach ON. Kompanie te znajdowały się w Tarnowskich Górach, Radzionkowie, Chorzowie, Świętochłowicach, Kochłowicach, Mysłowicach, Mikołowie, Pszczynie, Rybniku, Żorach, Będzinie, Olkuszu czy Sosnowcu. W tym czasie kompanie ON tworzono niemal w każdej większej miejscowości. Wytyczne działań wewnętrznych skupiały się na utworzeniu kordonu zabezpieczającego centrum województwa śląskiego. Dużą liczbę kompanii ON i oddziałów PW rozlokowano na zachód od Katowic. ${ }^{28}$

27 CAW-WBH, 23 DP, sygn. I.313.23.20, Sprawozdanie z realizacji programu P.W. Kierownika Rej. 23 Dywizji Piechoty L.dz. 477/tj./P.W. z dnia 15 V 1939 r., Katowice, 1.

28 Ibid. 
Jednym z najważniejszych zadań grup PW w przededniu wybuchu wojny na Śląsku była kontrola ruchu, zwłaszcza na tyłach. Służący w tych grupach mieli meldować oddziałom wojskowym o wszelkich spostrzeżeniach. Zachowana dokumentacja nie precyzuje konkretnych ruchów czy działań, które miały stać się przedmiotem obserwacji. Należy przyjąć, że zakładano tutaj szeroko rozumiane działania niemieckich grup dywersyjnych lub być może otwartych aktów wrogości wystąpień mniejszości niemieckiej. W tym celu utworzono rozbudowaną sieć tzw. ideowych wywiadowców. Ich szeregi zasilali właśnie członkowie oddziałów PW. ${ }^{29} \mathrm{~W}$ związku z szeroką działalnością PW tworzono specjalistyczne grupy, które miały realizować różne zadania o charakterze pomocniczym dla Wojska Polskiego.

Pierwsza ze specjalistycznych grup zajmowała się zadaniami saperskimi. Do nich należały głównie czynności minerskie. Grupy te szkolono w ośrodku saperskim w Mysłowicach. Junaków przydzielano głównie do placówek Straży Granicznej. Wraz z przeszkolonymi funkcjonariuszami Straży tworzyli patrole minerskie. Ich zadaniem było nadzorowanie terenów fabryki amunicji i materiałów wybuchowych w Łaziskach Górnych i zakładów Lignozy. Przy kopalniach tworzono górnicze PW, które miało nadzorować wydobycie i starać się zagwarantować spokój pracującym górnikom. Zajmowano się również patrolowaniem terenów kopalni w celu wykrycia kanałów przerzutu broni, nielegalnych broszur czy działaczy z terenu Rzeszy. Pod ziemią istniały bowiem chodniki, jeszcze z czasów przed podziałem Śląska, które wykorzystywali Niemcy jako drogi przerzutowe. PW kolejarzy zajmowało się nadzorem węzłów, stacji oraz transportu kolejowego. Kolej wówczas była istotna ze względów gospodarczych i strategicznych. Paraliż tej gałęzi transportu mógł mieć olbrzymi wpływ na gospodarkę województwa i działania wojska w obliczu spodziewanej wojny. Na terenie województwa śląskiego znajdowały się spore obszary zalesione, znajdujące się w rękach państwowych i prywatnych. W obu przypadkach opiekę nad nimi sprawowało PW gajowych. Przez lasy wiodło wiele szlaków przerzutowych, więc grupy te miały zabezpieczać teren i zapobiegać przerzutom. ${ }^{30}$ Wykorzystywano również konne PW. Plutony tej grupy przeważnie działały przy 3 Pułku Ułanów Śląskich, który stacjonował w Tarnowskich Górach. Rozlokowano je na obszarze całego województwa. Część sprzętu, głównie oporządzenie i mundury, zakupiono dzięki wsparciu ludności województwa śląskiego. W akcjach na ten cel zebrano 11 tys. złotych. W przypadku rozpoczęcia działań wojennych grupy te wchodziły w skład przypisanych, właściwych terytorialnie, oddziałów obrony narodowej.

29 Ibid., 1-2.

30 Zob. szerz. Zbigniew Zieliński, „Przysposobienie Wojskowe Leśników w latach 19331939," Niepodległość i Pamięć 12, nr 1 (2005): 197-214. 


\section{Przysposobienie wojskowe kobiet}

W okresie międzywojennym działalność kobiecych ruchów proobronych borykała się z różnorodnymi problemami. Przełożyło się to na mnogość organizacji, którym towarzyszyły równie liczne koncepcje umiejscawiania tych ruchów w ogólnopaństwowych strategiach PW. W pracy tej, tak jak wspomniano w początkowej części artykułu, określono je jako PW kobiet odnoszące się do struktur i działań kierowanych przez MSWojsk. i PUWFiPW. Należy jednak wspomnieć, że pomiędzy rokiem 1928 a marcem 1939 r. funkcjonowało Przysposobienie Kobiet do Obrony Kraju (PKdOK) jednoczące struktury państwowe i organizacje cywilne. W marcu $1939 \mathrm{r}$. PKdOK w okresie swojego rozkwitu przemianowano na Pogotowie Społeczne Przysposobienia Wojskowego Kobiet. Jeden ze zjazdów przedstawicielek kół PKdOK, związany z ideą przekształcenia, odbył się w 1938 r. w Katowicach. ${ }^{31}$ Ze względu na ograniczenie rozmiarów publikacji zagadnienia tych przemian organizacyjnych nie zostaną szerzej poruszone. Wyjątkowo potraktowano ogólny zarys struktur i umiejscowienia w nich samego PW kobiet. Szczegółowa zmiana strukturalna nie była na tyle znacząca, aby odmienić charakter pracy w regionach. Użyty w pracy skrót PKdOK ma na celu podkreślenie stosunków i relacji organizacji z ogólnym ruchem PW kobiet.

$\mathrm{Na}$ terenach pozbawionych struktur powiatowych PW obowiązki komendanta zazwyczaj pełniła kierowniczka placówki PW kobiet, w miejscowości będącej siedzibą powiatu. Jej kompetencje dotyczyły wówczas wyłącznie spraw kobiecego ruchu PW. Status zastępcy odnosił się do zakresu spraw kobiet, a nie do całości obowiązków przełożonego. Na pierwszy rzut oka schemat wydaje się podobny do męskiego PW. Najważniejsza różnica dotyczy powoływania najwyższych organów, które wybierano w czasie walnych zjazdów. Wyłoniona w tej drodze kandydatka zostawała później mianowana przez dowódców wojskowych. Oczywiście komendantki musiały przejść odpowiednie szkolenie i dopiero wówczas na stanowisko powoływał je PUWFiPW. ${ }^{32}$ Wydaje się, że pomimo pewnej demokratyzacji powoływania komendanta ostatecznie nie wybierano osób przypadkowych z punktu widzenia środowisk wojskowych.

Zwiększenie uczestnictwa kobiet w ogólnopaństwowym ruchu PW nastąpiło po $1935 \mathrm{r}$. Wynikało to z ostatecznego ukształtowania się struktur państwowych PW, które znalazły się w gestii wydziału WF i PW kobiet w ramach PUWFiPW kierowanego wówczas przez płk. dypl. Władysława

31 Zob. szerz. Elżbieta Zawacka, Szkice z dziejów wojskowej służby kobiet, t. 2 (Toruń: Wyd. Fundacja „Archiwum Pomorskie Armii Krajowej”, 2001).

32 Ibid., 2:30-48. 
Kilińskiego. ${ }^{33}$ Dopełnieniem kształtowania się struktur ogólnopaństwowych i regionalnych była ustawa o powszechnym poborze wojskowym z 1938 r., w której określono możliwość służby wojskowej kobiet w charakterze służby pomocniczej. ${ }^{34}$

Istotnym okresem dla śląskiego PW kobiet był $1936 \mathrm{r}$. W tym czasie pracę w Tarnowskich Górach rozpoczęła doświadczona organizatorka Elżbieta Zawacka. Po przybyciu na Śląsk podjęła pracę jako nauczycielka w Państwowym Gimnazjum Żeńskim oraz w tzw. liceum raciborzanek. Budowała lokalne i powiatowe koła PW kobiet, a w 1937 r. przeszła na bezpłatny urlop nauczycielski i pensję MSWojsk. W okresie jesiennym została skierowana na dwumiesięczny wyższy kurs instruktorski. Jego zakończenie wiązało się z mianowaniem na komendantkę Śląskiego Rejonu PW kobiet. Siedziba komendy i zarazem miejsce jej urzędowania znajdowało się wówczas przy ul. Kilińskiego w Katowicach. Struktury śląskiego PW kobiet w chwili objęcia stanowiska przez Zawacką były dobrze rozwinięte. Świadectwem tego było wyróżnienie śląskich struktur w postaci przejęcia pod opiekę sztandaru PW kobiet. Honorowano w ten sposób rejony szczególnie wyróżniające się swoją działalnością w roku poprzedzającym. Sztandar przejmowano na rok. Pod skrzydłami nowej komendantki struktury śląskiego PW kobiet rozbudowywały się dalej, ostatecznie obejmując siedemnaście powiatów. Do puli tej wliczono również powiaty znajdujące się na przyłączonym do Polski w październiku 1938 r. terenie Zaolzia. Niewątpliwymi sukcesami komendantki były zorganizowane dwa centralne kursy instruktorskie, rozbudowa sieci komend powiatowych oraz dziesięciu obozów pracy społecznej PW kobiet. $^{35}$

Próba oszacowania ilości i liczebności hufców PW kobiet napotyka podobne trudności, jak w przypadku ogólnego PW (zob. tabela 4). Również ruch PW kobiet miał swoją reprezentację w większości ważnych miejscowości województwa. Ewidentnie mniejsza liczba hufców niż w przypadku męskiego PW wynika z ograniczonych środków, mniejszej liczby szkół żeńskich oraz naturalnego mniejszego zainteresowań kobiet sprawami wojskowości.

33 Michalina Wittek, „Służba wojskowa kobiet w Polsce od I wojny światowej do okupacji we wrześniu 1939 r." w Stużba Polek na frontach II wojny światowej, cz. 8, Z dziejów Przysposobienia Wojskowego Kobiet $i$ Wojskowej Stużby Kobiet (materiały), red. Zawacka (Toruń: Wyd. Fundacja Generał Elżbiety Zawackiej, 1999), 203; Wojtycza, „Państwowy Urząd” 85.

34 Ustawa z dnia 9 kwietnia 1938 r. o powszechnym obowiązku wojskowym (Dz. U. 1938, nr 25 poz. 220, art. 8, 102-105).

35 Katarzyna Minczykowska, Cichociemna Generał Elżbieta Zawacka „Zo” 1909-2009 (Toruń: Ofic. Wyd. Rytm, 2014), 63-65. 
Tabela 4. Wykaz hufców szkolnych PW kobiet.

\begin{tabular}{|c|c|c|}
\hline Lp. & Miejscowość & Szkoła \\
\hline 1. & Tarnowskie Góry & Gimnazjum \\
\hline 2. & Katowice & Szkoła zawodowa; Gimnazjum \\
\hline 3. & Mysłowice & Gimnazjum \\
\hline 4. & Roździeń & Gimnazjum \\
\hline 5. & Pszczyna & Gimnazjum \\
\hline 6. & Nowa Wieś & Seminarium \\
\hline 7. & Chorzów [daw. Królewska Huta] & Gimnazjum; Szkoła handlowa \\
\hline 8. & Rybnik & Szkoła handlowa; Szkoła rzemiosła \\
\hline 9. & Rybnik & Gimnazjum \\
\hline 10. & Bielsko & Szkoła zawodowa; Szkoła dokształcająca \\
\hline 11. & Cieszyn & Szkoła handlowa; Gimnazjum; Seminarium \\
\hline 12. & Mikołów & Gimnazjum \\
\hline 13. & Siemianowice & Gimnazjum \\
\hline 14. & Żory & Gimnazjum \\
\hline
\end{tabular}

Źródło: Opracowanie własne autora na podstawie dokumentacji Wydziału Oświecenia Publicznego Urzędu Wojewódzkiego Śląskiego: AP w Katowicach, Urząd Wojewódzki Śląski w Katowicach, 12/27/0/13.1/548, Organizacja i zadania żeńskich hufców szkolnych przysposobienia wojskowego w latach 1932-1938.

We wszystkich powiatach $\mathrm{w}$ omawianym regionie komendantki PW kobiet powoływano właściwie od 1938 r. Do głównych ich zadań należała inicjacja prac i koordynacja szkoleń na terenie danego powiatu. Podobny schemat obowiązywał w przypadku komendantek kół miejscowych. Problemem dla PW kobiet były niskie dotacje przeznaczone na ten cel. Finanse kobiecych organizacji próbowano ratować środkami PW i WF. ${ }^{36}$ Stosunkowo późny rozwój struktur PW kobiet w województwie śląskim, jak i w całym kraju, wynikał ze wspomnianych wcześniej ograniczeń finansowych. Większość środków finansowych i subwencji trafiała do różnych struktur i organizacji męskiego PW, władze traktowały je bowiem priorytetowo, przyjmując, że to mężczyźni ponoszą główny ciężar trudów wojennych. Nie oznacza to, że nie dostrzegano zalet PW kobiet.

W województwie śląskim PW kobiet rozszerzyło swoją działalność dzięki zawarciu współpracy z Katolickim Stowarzyszeniem Kobiet (KSK). Akcja PKdOK została włączona do programu KSK na podstawie decyzji podjętej na zjeździe delegatek w Cieszynie 30 kwietnia 1939 r. Delegatki uchwaliły wówczas następującą rezolucję: „Świadome zadań i obowiązków, które

36 CAW-WBH, 23 DP, sygn. I.313.23.13, Pismo Ministerstwa Spraw Wojskowych[,] Państwowy Urząd Wychowania Fizycznego i Przysposobienia Wojskowego, nr 1338/Tj./kob. Warszawa, 16 VIII 1938 r., 1-3. 
obecne czasy nakładają na kobietę katoliczkę i Polkę wzywamy wszystkie członkinie, aby w chwilach tak wielkiej wagi dla naszej Ojczyzny, ufne w Opatrzność Bożą, zachowały zupełny spokój we własnej duszy, w swej rodzinie i w organizacji oraz, by się przejęły duchem ofiary na rzecz obrony narodowej, duchem męstwa, wytrwałości i postanawiamy zorganizować w swych oddziałach informacyjne kursy obrony przeciwgazowej i kursy specjalne". Katolicki Związek Kobiet, nadrzędny dla KSK jako centrala krajowa, zgłosił swój akces do organizacji PKdOK w Warszawie na członka współdziałającego. Wszelkie kursy i akcje organizowane były autonomicznie przy pomocy organizacji specjalistycznych. Należały do nich m.in. Liga Obrony Powietrznej i Przeciwgazowej, ośrodki lokalne PKdOK i Polski Czerwony Krzyż. ${ }^{37}$

Prymas Polski listem z 12 kwietnia 1939 r. wyraził zgodę na nawiązanie współpracy KSK z ruchem PW kobiet. Efektem porozumienia nie była fuzja organizacji, lecz przyłączenie do ruchu PKdOK. Dla członkiń przygotowywano kursy specjalizacyjne na Śląsku. Jeden z nich miał miejsce na Panewnikach (dzielnica Katowic) w Domu Pątniczym Ojców Franciszkanów. Kurs trwał od 12 do 17 czerwca 1939 r. Program zakładał następujące tematy: zadania kobiety $\mathrm{w}$ obronie kraju $\mathrm{z}$ uwzględnieniem zadań pogotowia społecznego; samoobrona gospodarcza z punktu widzenia życia wojennego; obrona przeciwgazowa i przeciwlotnicza; opieka nad dzieckiem; higiena i ratownictwo; przygotowanie moralne. Kurs ten miał charakter wojskowy, więc w czasie trwania obowiązywał rygor jak w wojsku. ${ }^{38}$ Przejawiało się to choćby w swoistym „skoszarowaniu” we wspomnianym domu pątniczym na czas szkolenia czy rozplanowaniem porządku dnia na wzór obowiązujących w czynnej służbie. Oczywiście z zachowaniem dyscypliny i podporządkowania prowadzącym kurs instruktorom.

Poruszane na kursie tematy pozwalają się odnieść do zagadnień omawianych na innych kursach. Nie miały one przygotować kobiet do bezpośredniej walki „z bronią w ręku”, lecz do radzenia sobie w trudnych sytuacjach wojennych. Zapewnienie bezpieczeństwa ich rodzinom, niesienie pomocy potrzebującym i wykształcenie odpowiednich zachowań na wypadek ataku z powietrza czy gazowego to zadania, które są przede wszystkim istotne dla społeczeństwa. Działalność na tym polu odciążyłaby struktury państwowe skupione na działaniach wojennych. W okresie pokojowym zadania PW

\footnotetext{
37 Ibid, Wycinek prasowy nieznanej gazety dot. zawarcia współpracy pomiędzy Katolickim Stowarzyszeniem Kobiet a Wojskowym Przysposobieniem Kobiet, b.m., b.d., b.p.

38 Ibid., Okólnik w sprawie kursu instrukcyjnego Przysposobienia Kobiet do obrony kraju, zorganizowanego dla delegatek Oddziałów Katol. Stow. Kobiet. Na który każdy oddział winien zgłosić jedną delegatkę wydany przez Katolickie Stowarzyszenie Kobiet w Katowicach dn. 9 VI 1939 r., [Katowice], 1-2.
} 
kobiet wiązały się z rozbudową struktur, organizowaniem szkoleń dla jak najszerszego grona i działalnością propagandową.

Powyższy przykład łączenia sił poszczególnych organizacji kobiecych i prowadzenia szkoleń PW wpisywał się w szerszą politykę PW kobiet na Śląsku w 1939 r. W obliczu rosnącego zagrożenia konfliktem zbrojnym, zwłaszcza niebezpiecznym dla przygranicznego i wielonarodowego obszaru, starano się nawiązać współpracę z możliwie najszerszą grupą organizacji społecznych. Wzmocnieniem ruchu było nawiązanie współpracy również z Kołem Polek działającym na obszarach wiejskich. Wyrazem łączenia sił był dzień 31 marca 1939 r., kiedy to 24 przedstawicielki śląskich organizacji kobiecych powołały w Katowicach Ośrodek Propagandy. Przejawem działalności były organizowane wiece, pochody i nadawane w każdą środę od początku sierpnia audycje radiowe. Podczas nich wygłaszano referaty tematyczne z materii PW i prowadzono działalność agitatorską na rzecz wspierania wojska i państwa. ${ }^{39}$

\section{Podsumowanie}

Struktury PW podległe 23 DP wpisują się w ogólnopaństwowe schematy. Tworzenie rejonów przy dowództwach dywizyjnych było częstym zjawiskiem. Za odstępstwo należy przyjąć przekazanie zwierzchności nad strukturami PW znajdującymi się na obszarze stacjonowania oddziałów sąsiedniej 21 DPG. Prace Piotra Sai, poświęcone PW na Pomorzu, nie przedstawiają takich sytuacji. Ze względu na niedosyt opracowań dotyczących PW również trudno jednoznacznie określić, czy wskazany przykład jest wyjątkiem DOK nr V, czy stosowanym $\mathrm{w}$ innych częściach państwa zjawiskiem. Z całą pewnością nie miał on jednak charakteru powszechnego w przypadku ogólnego ruchu PW. Rozpoczęcie tworzenia rejonu PW w Katowicach miało miejsce w latach 1927-1929. Świadczy to o znaczeniu regionu w założeniach PW dla władz państwowych. W obliczu wybuchu wojny z Niemcami władze wojskowe zdecydowały się na wykorzystanie oddziałów PW do wzmocnienia bezpieczeństwa i obronności obszaru polskiego Śląska i okolicznych terenów. Dowództwo dywizji musiało doceniać znajomość terenu województwa i konkretnych miejscowości w lokalnych oddziałach PW. Wątpliwości nie mogła także budzić ich lojalność. W innym przypadku nierealne byłoby tworzenie sieci ideowych wywiadowców. Podejmując się oceny PW rejonu $23 \mathrm{DP}$ w przededniu wybuchu wojny, należy czynić to pod kątem możliwości i przydatności operacyjnej działań obronnych. Możliwość tworzenia licznych jednostek ON różnego szczebla na tym obszarze świadczyła o dobrym przygotowaniu społeczeństwa do służby wojskowej

Minczykowska, Cichociemna, 66. 
i o dużym poparciu dla idei PW. Dowództwo dywizji dostrzegało potencjał w wykorzystaniu ruchu PW dla wzmocnienia bezpieczeństwa regionu, decydując się na tworzenie wyspecjalizowanych grup w postaci gajowych, kolejarzy czy przydzielając członków PW po przeszkoleniu do patroli minerskich. Niepoprzestanie na utworzeniu i przypisanie im konkretnych zadań jest świadectwem sprawności i użyteczności struktur PW dla wojska.

Omawiany region cechowała obecność silnej mniejszości niemieckiej. W zachowanej dokumentacji dywizyjnej brak wzmianek o infiltracji czy sabotowaniu działań w sferze PW. Prawdopodobnie konspiracyjne organizacje niemieckie skupiały uwagę na wojsku, administracji państwowej i organizacjach paramilitarnych, takich jak Związek Rezerwistów czy Związek Powstańców Śląskich.

Siła PW przy 23 DP wynikała z patriotyzmu miejscowego społeczeństwa, ale istotne znaczenie miała działalność osób dalece zaangażowanych działalność związaną z PW, jak płk Giza czy Zawacka. Mieszkańcy regionu angażowali się w ruch PW, czego wyrazem było stworzenie w przededniu wojny licznych pododdziałów ON. Górnośląska Brygada ON, przekształcona w 55 DPRez., składała się z m.in. członków śląskiego PW. Liczebność i siła ruchu pozwoliła na stosunkowo sprawne wystawienie dużej formacji w postaci DPRez., ale i licznych kompanii ON w większości śląskich miast. Nie byłoby to możliwe bez zaangażowania się społeczeństwa właściwie $\mathrm{w}$ całym okresie międzywojennym bezpośrednio w ruch. Tworzenie licznych jednostek ON wymagało stosunkowo dużego zaplecza wykwalifikowanego personelu, który pozyskiwano częściowo właśnie ze struktur PW. Wybitne jednostki realizujące się w ramach tego ruchu przydzielano do jednostek ON. Dzięki ofiarności mieszkańców była to też jedna z najlepiej wyposażonych jednostek tego typu. Dowództwo brygady objął płk Giza, stając wówczas na czele ludzi, których szkolenie nadzorował. Sprawność w działaniu na tym polu przełożyła się też na otrzymanie awansu do stopnia gen. bryg. Kobiece struktury PW, w przededniu wojny, były również jednymi $\mathrm{z}$ najlepiej rozwiniętych $\mathrm{w}$ państwie. $\mathrm{W}$ czasie okupacji niemieckiej osoby związane z ruchem PW włączyły się w działalność organizacji niepodległościowych na Śląsku.

\section{Bibliografia}

\section{Archiwalia}

Centralne Archiwum Wojskowe Wojskowego Biura Historycznego

23 Dywizja Piechoty

Archiwum Państwowe w Katowicach

Urząd Wojewódzki Śląski w Katowicach 


\section{Akty prawne}

Deklaracja między Polską a Niemcami o niestosowaniu przemocy, podpisana w Berlinie dnia 26 stycznia 1934 r. (Dz. U. 1934, nr 16, poz. 124).

Ustawa z dnia 9 kwietnia 1938 r. o powszechnym obowiązku wojskowym (Dz. U. 1938, nr 25, poz. 220).

Zarządzenie Ministra W. R. i O. P. oraz Ministra Spraw Wojskowych z dnia 10 września 1937 r. w sprawie organizacji przysposobienia młodzieży szkolnej do obrony kraju (Dz. Urz. Ministra Wyznań Religijnych i Oświecenia Publicznego, nr 12, poz. 369,439$)$.

\section{Opracowania}

Falęcki, Tomasz. Powstańcy śląscy 1921-1939. Wrocław-Warszawa: Wyd. Volumen, 1990.

Fularski, Mieczysław. Przysposobienie wojskowe w Polsce. Warszawa: Wyd. Głównej Księgarni Wojskowej, 1929.

Giza, Józef i Tomasz Podgórski. Generał Józef Giza 1887-1965 Virtute et armis. Nowy Sącz-Kraków: Wyd. Flexergis, 2015.

Giza-Podgórska, Maria. Z Sącza rodem wspomnienia córki generała Józefa Gizy. Nowy Sącz: Wyd. Sądecka Ofic. Wyd., 1993.

Hildebrandt, Józef. „Zinstytucjonalizowane przysposobienie wojskowe w Polsce w latach 1918-1939." Zeszyty Naukowe Wyższej Szkoły Pedagogicznej w Bydgoszczy Studia z Nauk Społecznych 11, (1994): 77-89.

Kęsik, Jan. Naród pod bronią, Społeczeństwo w programie polskiej polityki wojskowej 1918-1939. Wrocław: Wyd. Uniwersytetu Wrocławskiego, 1998.

Minczykowska, Katarzyna. Cichociemna Generał Elżbieta Zawacka „Zo” 1909-2009. Toruń: Ofic. Wyd. Rytm, 2014.

Niederliński, Wojciech. „W wolnej Polsce. Harcerstwo męskie w latach 1922-1939.” W Z dziejów harcerstwo śląskiego Rozwój i działalność harcerstwa na Górnym Ślasku w latach 1920-1945. Red. Wojciech Janota, 24-78. Katowice: Wyd. „Śląsk”, 1985.

Odziemkowski, Janusz. Armia i społeczeństwo II Rzeczypospolitej. Warszawa: Bellona, 1996.

Pindel, Kazimierz. Obrona terytorialna w II Rzeczypospolitej. Warszawa: Bellona, 1995.

Pindel, Kazimierz. Śląsk $w$ systemie obronnym II Rzeczypospolitej. Warszawa: Bellona, 1998.

Saja, Piotr. Komitety wychowania fizycznego i przysposobienia wojskowego $w$ województwie pomorskim w okresie drugiej Rzeczypospolitej. Toruń: Piotr Saja, 2021.

Saja, Piotr. „Przygotowanie wojskowe młodzieży szkolnej i obozy letnie przysposobienia wojskowego ogólnego męskiego na Pomorzu pod koniec lat dwudziestych i w latach trzydziestych XX wieku." Przeglad Historyczno-Wojskowy 20 (71), nr 2 (268) (2019): 28-54. http://dx.doi.org/10.32089/WBH.phw.2019.2(268).0002.

Szefer, Andrzej. „Prowokacje hitlerowskie na Górnym Śląsku w przededniu agresji niemieckiej na Polskę w 1939 r.” W Śląsk wobec wojny polsko-niemieckiej 1939. Red. Wojciech Wrzesiński, 129-138. Wrocław-Warszawa: Wyd. Volumen, 1990.

Wittek, Michalina. „Służba wojskowa kobiet w Polsce od I wojny światowej do okupacji we wrześniu 1939 r.” W Służba Polek na frontach II wojny światowej. Cz. 8, 
Z dziejów Przysposobienia Wojskowego Kobiet i Wojskowej Służby Kobiet (materiaŁy). Red. Elżbieta Zawacka, 193-234. Toruń: Fund. Armii Krajowej, 1999.

Wojtycza, Janusz. „Państwowy Urząd Wychowania Fizycznego i Przysposobienia

Wojskowego jako element koordynacji systemu bezpieczeństwa w II RP w latach 1927-1939.” Bezpieczeństwo Teoria i Praktyka 5, nr 2 (2012): 79-86.

Wojtycza, Janusz. Przysposobienie Wojskowe w odrodzonej Polsce do roku 1926. Kraków: Wyd. Naukowe Akademii Pedagogicznej, 2001.

Zaczyński-Zaczek, Krzysztof. „Programy przysposobienia wojskowego w II Rzeczypospolitej" Przysposobienie Obronne i Obrona Cywilna w Szkole, nr 4 (1992).

Zawacka, Elżbieta. Szkice z dziejów wojskowej służby kobiet. T. 2. Toruń: Wyd. Fundacja „Archiwum Pomorskie Armii Krajowej”, 2001.

Zieliński, Zbigniew. „Przysposobienie Wojskowe Leśników w latach 1933-1939.” Niepodległość i Pamięć 12, nr 1 (2005): 197-214.

\section{STRESZCZENIE}

Kamil Kołodziej, Przysposobienie wojskowe podległe 23 Górnośląskiej Dywizji Piechoty u schyłku lat trzydziestych XX w. Organizacja i zasady działania

Tematyka przysposobienia wojskowego w okresie międzywojennym była przedmiotem wielu badań. Pomimo tego zauważalny jest brak publikacji poświęconych regionalnym działaniom PW, zwłaszcza dla obszarów wielonarodowych i przygranicznych. Artykuł obejmuje lata 1937-1939, odnosząc się do okresu funkcjonowania i rozbudowy struktur PW podległych 23 Górnośląskiej Dywizji Piechoty, który zbiegł się z przygotowaniami do nadchodzącej wojny polsko-niemieckiej. Praca przedstawia struktury PW na obszarze stacjonowania 23 Dywizji Piechoty, cele i zadania operacyjne oraz współpracę z cywilnymi organizacjami realizującymi założenia PW. Istotnym elementem jest ocena możliwości i sprawności śląskich struktur PW, jako obszaru z silną mniejszością niemiecką, w obliczu nadchodzącej wojny.

Słowa kluczowe: Wojsko Polskie, II Rzeczypospolita, przysposobienie wojskowe, Górny Śląsk, województwo śląskie

\section{SUMMARY}

\section{Kamil Kołodziej, Military training subordinate to the 23rd Upper Silesian Infantry Division at the end of the 1930s. Organization and operating principles}

The matter of military training (PW) during the interwar period has been the subject of many studies. Despite this, there is a noticeable lack of publications concerning the regional activities of the PW, especially regarding multinational and 
border areas. This article covers the years 1937-1939, which was a period that saw the expansion of PW training structures subordinate to the 23rd Upper Silesian Infantry Division, which coincided with preparations for the expected Polish-German war. The work presents the PW structures in the area where the 23rd Infantry Division were stationed, operational goals and tasks, as well as the cooperation that occurred with civilian organizations regarding assessments of the efficiency of Silesian PW structures as an area with a strong German minority.

Keywords: Polish Army, Second Republic of Poland, military training, Upper Silesia, Silesian Voivodeship

\section{АННОТАЦИЯ}

\section{Камиль Колодзей, Военная подготовка (PW), подчиняющаяся 23-й Верхнесилезской пехотной дивизии, в конце 1930-х годов. Организация и принципы работы}

Вопрос о военной подготовке в межвоенный период был предметом многих исследований. Несмотря на это, ощущается значительная нехватка публикаций о региональной деятельности организаций военной подготовки, особенно в многонациональных и приграничных регионах. Данная статья охватывает 1937-1939 годы в контексте периода функционирования и расширения структур военной подготовки (PW), подчиняющейся 23-й Верхнесилезской пехотной дивизии, что совпало с подготовкой к предстоящей польско-германской войне. В работе представлены структуры PW на территории дислокации 23-й пехотной дивизии, оперативные цели и задачи, а также взаимодействие с гражданскими организациями, реализующими цели организаций военной подготовки. Важным элементом является оценка возможностей и эффективности силезских структур PW (как территории с сильным немецким меньшинством) перед лицом надвигающейся войны.

Ключевые слова: Войско Польское, Вторая Речь Посполитая, военная подготовка, Верхняя Силезия, Силезское воеводство 